\title{
School and the value of knowledge: Transformations in Belarusian jokes about education
}

\author{
Anastasiya Fiadotova \\ University of Tartu \\ zhvaleuskaya@gmail.com
}

\begin{abstract}
Over the past century Belarus has experienced a dramatic increase in educational level. Obtaining secondary education is now considered normal, getting a university degree is prestigious. However, such an attitude is relatively new to Belarusian society. Joke texts that date back to the 19th and the beginning of the 20th century indicate that formal education was widely considered useless, as it did not equip children with skills they needed in real life. Formal education was often contrasted with learning necessary skills at home, invariably in favour of the latter. In the Soviet era, formal education was made compulsory and suddenly became an integral part of people's lives, but it still lacked a link with children's future careers. Parents could not always appreciate the benefits of education, but had to send their children to school anyway. The clash between the "old" attitude and the "new" reality produced jokes. Jokes that have emerged in the post-Soviet era reflect the omnipresence of education in contemporary Belarusian society. Some school jokes point to a greater understanding of the value of knowledge in modern children-yet it is often not the formal knowledge they are expected to get in school. Overall, school in jokes has become a setting where issues prominent in society at large come to the fore, even if this goes against the will of the educators.
\end{abstract}

Keywords: joke, education, school, Belarus, folklore.

\section{Introduction}

The system of primary and secondary education is one of the crucial and most pervasive socialising agents in contemporary Belarus. However, the significance Belarusian society attaches to it is relatively recent. Over the past two centuries, education in Belarus has undergone dramatic changes both in terms of its content and its outreach. These transformations have been accompanied by changes in people's attitudes towards education as a whole and primary and secondary school in particular. The changing attitudes were reflected, among other sources, in numerous jokes.

In this paper I will attempt to link the evolution of Belarusian formal education to the changes in jokes about school. In order to do so, I will analyse three sets of jokes about primary and secondary education. The first group dates back to the 19th and early 20th century and 
corresponds to the time when Belarus was a part of the Russian empire. The second set comprises Soviet jokes about education. The third group is a corpus of contemporary Belarusian jokes on the same subject matter. While I will analyse these three sets separately, I will attempt to maintain a focus on the continuity and change in joke topics over two centuries. On a larger scale, following Frolova's idea that jokes are a window into "extralinguistic reality" (Frolova 2010: 41-42), I aim to show the transformations in Belarusian society through the lens of jokes about education.

The second section of the paper is a brief overview of Belarusian folk joke research. It also touches upon the existing work linking jokes and education in contemporary humour studies. In the third section I will describe my methodology and discuss some complexities of working with heterogeneous joke sources. I will also define my object of study ("Belarusian joke about primary or secondary education"). The fourth section traces the historical development of education in Belarus, which provides an overview of the changing context in which the jokes emerged and circulated. Sections five, six and seven are dedicated to joke analysis proper, with each section focusing on one of the three periods.

\section{Belarusian jokes and jokes about education in folklore studies}

\subsection{Defining the key terms}

Finding and choosing joke sources for a study that covers such a long period of time is a complicated matter. This is in part because both the jokes themselves and the terms describing jokes as a folk genre have changed their meaning overtime.

The most common term used in contemporary East Slavic folklore studies to describe a short humorous narrative that ends with a punch line is "anecdote" ('анекдот' in Russian and Belarusian). Its structure and comic mechanisms are similar to those found in a joke (Russian 'шутка', Belarusian 'жарт'). But even though the genre of "anecdote" was already known in the region in the 18th century (Yarnevsky 1969: 109), it normally signified a literary anecdote: an amusing story involving a famous historical figure that may or may not be funny (Petrovsky 1925). Such anecdotes circulated in a narrow circle of educated and noble people and were unknown to the vast majority of the largely peasant Belarusian population.

Only in the middle of the 20th century did the term "anecdote" acquire a unified meaning (Arkhipova 2013: 21), being now defined as "a very short tale with funny content and an unexpected witty ending" (Ozhegov \& Shvedova 1998: 25). This is similar to the definition of the English term 'joke': "a brief story with a surprising and funny ending" (MerriamWebster.com). The present study is based on this newer definition of "anecdote"/"joke" and does not cover literary anecdotes of the 19th and early 20th century.

In addition to the concerns and limitations described above, there is also the question of how to define a "Belarusian joke". This question is particularly pertinent when discussing Soviet and post-Soviet jokes. The folk joke sources dating back to the Russian Empire usually specified the area the jokes had been collected from, and most of the jokes found in presentday Belarus were in fact in the Belarusian language. However, during the Soviet period most Belarusians adopted Russian as their native language and around $70 \%$ of Belarusians speak Russian on a daily basis today (Population census in Belarus 2009: 9). Naturally, these people exchange jokes in Russian as well, easily borrowing them from other Russian-speaking countries. This means that there is no way to unequivocally delineate between Belarusian jokes and other jokes in Russian. However, in order to keep the focus within the intended ethnic boundaries, I included only those Soviet era jokes that were published in the Byelorussian 
Soviet Socialist Republic by or in collaboration with professional philologists and folklorists and were explicitly marked as Belarusian jokes.

Another important question is what constitutes a "joke about education" and what kinds of education to investigate. In this paper, I will only focus on formal primary and secondary education. Jokes about university students and their life are beyond the scope of this paper as they are tightly connected to the student subculture (Astapova 2016). In the 19th century Belarus had no universities and student subculture as such. There were fraternities of Belarusian students in Moscow, St. Petersburg and other neighbouring university centres, but they were not numerous, and neither, to the best of my knowledge, were their jokes publicised. Only in the 20th century (especially in its second half) did higher education become widespread in Belarus and so did jokes about university students. Therefore, these jokes have little potential for use in a diachronic analysis spanning over a century.

Jokes about school do not constitute a definite joke cycle. Even though they share a common subject, they lack other links such as common narrative strategy, logical mechanism, etc. that are equally or even more important in defining a joke cycle according to the General Theory of Verbal Humour (Attardo 2001: 69). However, jokes about education encompass some jokes from various popular joke cycles such as the Vovochka joke cycle which will be discussed further in this paper, the New Russian joke cycle (jokes satirising the perceived stupidity and the excessive consumption habits of the post-Soviet nouveaux riche), and so on.

In this paper I differentiate jokes about education from "school folklore": folk texts that are created by school children themselves and circulate at schools and other educational institutions. Even though these two types of folk genres are closely connected, they are not equivalent. School folklore is not necessarily humorous and may cover topics that are not related to education (for example, absurdist poetry cited in Belousov (1998: 8). It is represented by various genres and it reflects children's mentality and various rituals in their school life (e.g. Akhmetova 2009). Jokes about education are more homogeneous and address a larger audience which consists primarily of adults.

For the purposes of this research I selected jokes that had pupils and/or teachers as their protagonists. However, I did not limit the joke settings to the school or the classroom, and some of the jokes also feature other characters such as school officials, relatives (mainly pupils' parents) or friends. Jokes were included in the sample if they featured at least one of the following keywords: "school", "teacher", "pupil”, "classroom", "lesson", "homework". This only makes them "jokes about education" in the most general sense, as many of these jokes derive humour not from education itself, but from a broader context of social life.

\subsection{Remarks on the collection and publication of folk jokes in the 19th to early 20th century and in the Soviet period}

Belarusian folk jokes have been collected and published by ethnographers, folklorists and other scholars since the 19th century. Most of these scholars represented the Russian Academy of Sciences, the Russian Geographical Society and other academic institutions or conducted private expeditions. They typically collected jokes from the rural population. However, these joke publications had their limitations. Some of these early works showed a markedly disparaging attitude towards Belarusians: Severgin, for example, described Belarusians as rough and ignorant people (1804: 95). Researchers, therefore, might have omitted some data which they deemed insignificant. Other field researchers (Yan Barshcheuski, Uladzislau Syrakomlya, etc.), on the contrary, adopted a Romanticist perspective and tended to increase the artistic value of the material they collected (Lobach 2006: 18). The material they published was more "refined" than the actual folk texts in oral circulation, which is evident, for example, from the fact that the jokes published by them did not contain any vulgar or profane language. 
It is also worth considering that these researchers were outsiders to the rural population and were not necessarily trusted enough to gain complete access to the communities' folklore traditions. Finally, due to the censorship in the Russian Empire, not all of the collected materials could be published at the time. Some of the jokes were compiled and published by folklorists only decades later.

The relative importance of different subject matters has not been a constant, either. Most rural dwellers in the 19th and the beginning of the 20th century did not have an opportunity to get even a primary education. Consequently, the issue of education was not among the popular topics of rural folklore and the number of folk jokes about education at the time was relatively small.

Collecting Soviet jokes also had some peculiarities. On the one hand, the Soviet epoch witnessed an unprecedented increase in the number of jokes and their diversity. This can be explained by intensive political propaganda and rapid urbanisation that led to the establishment of the joke as the most popular urban folklore genre (Melnichenko 2014: 10). Immediately before and after the October Revolution a great number of satirical and humorous papers and magazines emerged and became popular. Alongside literary humour, they featured some jokes, generally of the political kind (Shmeleva \& Shmelev 2005). However, these jokes were fairly uniform and aimed at disparaging the Communists' political opponents. Furthermore, Soviet satirical magazines such as Crocodile in Russia, Perec in Ukraine and Vozhyk in Belarus were heavily censored and published folk jokes in a distorted form (Melnichenko 2014: 34). Professional folklorists also encountered severe constraints on their collection, publication and research on jokes. Telling and sharing "anti-Soviet" jokes was criminalised and could lead to imprisonment according to the infamous article 58-10 of the Soviet penal code, which prohibited anti-Soviet agitation and propaganda (Arkhipova \& Melnichenko 2011: 25). These factors contributed to a considerable discrepancy between the corpus of published jokes and the variety of jokes in oral circulation.

This caveat concerns, among other jokes, the jokes about education. Being a powerful ideological tool, school education was compulsory and served to impose the state's authority on children and their parents. This authority was not to be questioned; therefore, published jokes did not question the ideological foundations of education or its clear link with the politics of the Communist party.

During the late years of the USSR and after its demise censorship in mass media has diminished, leading to a great outburst of joke sources. Newspapers, magazines, joke books seem to provide a vast range of jokes for analysis. However, it is uncertain whether the jokes disseminated in the media are representative of the oral tradition. Moreover, some researchers point out that the oral tradition itself is not as popular as it used to be in the Soviet times and the main medium of joke circulation is now the Internet (Alekseevsky 2010).

Jokes found on the Internet, however, are not equivalent to the ones circulating orally both in terms of their form and the context in which they circulate. They are transmitted in a different communication setting and do not demand an immediate reaction (Oring 2012: 101), but they are still "essentially archived and then selected for oral reenactment or private amusement" (Bronner 2012: 121) and thus constitute a valuable source for folklore research.

\subsection{Research on Belarusian jokes and jokes about education}

Full-scale academic studies of Belarusian folk jokes did not emerge until the late decades of the Soviet era and the decades following the country's independence. Prior to that Belarusian folk humour was only mentioned briefly in ethnographic and folkloristic studies (e.g. Serbov, 1915: 39, Karski 1916: 473). In the Soviet period the studies were scarce and largely took one of the two forms: introductions to joke books (e.g., Gilevich 1970; Kahanouski 1989) or 
subsections in papers or monographs about folklore in general (e.g., Kabashnikau 1969; Akhrymenka 1962). These introductions and monographs were mostly compiled by Belarusian State University professors, writers and journalists. Usually, they provided brief overviews of the entire body of Belarusian folk jokes without giving any detailed consideration to specific themes such as education. Moreover, studies published during the Soviet period were heavily influenced by the communist ideology and regarded jokes as an ideological weapon of the proletariat against the bourgeoisie (Kahanouski 1989: 3; Yankouski 1983a, 1983b). This perspective could be observed in the works of Anatol' Fiadosik $(1971,1978)$, one of the most prominent humour scholars in Soviet Byelorussia. Although he did conduct a pioneering and insightful study of the genres and plots of Belarusian jokes of the 19th and 20th century, Fiadosik paid little attention to jokes about education.

Even after the collapse of the USSR folk jokes still remain an underrepresented area of study in Belarusian folkloristics. Works on folk humour are scarce and do not always focus on jokes, let alone jokes about education. One of the few relevant examples is a paper by Mikhail Ken'ka titled "On the history of the Belarusian joke" (Ken'ka 2009). This paper focuses more on ethnic jokes (though lacking a proper definition of them) and does not address the issue of education in Belarusian folk humour.

The most relevant and comprehensive study of Russian and Belarusian folk jokes about education was provided by Anastasiya Astapova in her thesis "Contemporary student jokes: the body of text and their genetic relations" (Astapova 2012, 2016). The thesis focuses on contemporary student jokes and includes both an analysis and an extensive corpus of student jokes. It also compares student jokes with other joke corpora, including the jokes about primary and secondary education.

If we look for studies linking jokes to education beyond the Belarusian context, it becomes evident that most scholars tend to focus on the role of jokes in the social relations among school students and between students and their teachers (Walker \& Barton 2013, Frio 2012, Markie 1994). These studies are situation-specific, analysing the jokes' use in a particular context rather than jokes themselves. Jokes may be also analysed in a broader context of school life and school discipline (Maslinsky 2013).

A different approach is adapted in Elizabeth Radin Simons' "The NASA Joke Cycle: The Astronauts and the Teacher" (Simons 1986). The second part of her paper is dedicated to jokes about Christa McAuliffe, the teacher who was on board the Space Shuttle Challenger that exploded on 28 January 1986. Simmons analyses these jokes in relation to the American system of secondary education, linking their narratives of McAuliffe's stupidity to the perceived deficiencies in American education. The same approach is used by Ilchenko and Panchenko (2012) in their paper on a popular joke plot about women's reaction towards sexual jokes told mainly in the classroom, but also in the knitting group, at home or elsewhere. In this paper I will try to adopt a similar approach by analysing a larger corpus of jokes about Belarusian primary and secondary school in the context of the development of education in Belarus.

\section{Methodology and joke sources}

This paper is based primarily on qualitative methods, though some quantitative data are also taken into account. I combine the analysis of the jokes' texts with context analysis, situating the jokes' narratives in the context of the educational system of the given period in an attempt to glean insights into the "extralinguistic reality" (Frolova 2010: 41-42) underlying them, that is the values and attitudes associated with education at the time. It should be noted, however, that the relationship between jokes and reality is not straightforward (Laineste 2013: 487). Some researchers point out that jokes reflect only superficial levels of reality (Abrahams 1976) 
or reflect reality in a distorted way (Arkhipova 2012). It is therefore inaccurate to assume that jokes about school present a complete and undistorted reflection of people's perceptions concerning education, yet they still provide us with insights into these perceptions.

The paper has a diachronic focus, wherein the joke corpora of the three epochs (late Russian Empire, Soviet, post-Soviet) are subjected to a comparative analysis. This approach is in line with the general tendency in folklore studies to focus on the transformation and evolution of folk forms and plots overtime, as tracing the origins of folk texts is often impossible (Arkhipova 2003: 7). In a few cases the jokes cited in this paper are supported by similar examples from Russian and Ukrainian folklore.

The 19th and early 20th century jokes analysed in this paper come from three joke compilations that were published by professional philologists and folklorists: "Narodnyja usmeshki" (1961), "Smejcesya na zdaroue!" (1987) and "Zharty, anekdoty, gumareski" (2005). Most of the jokes (12 out of 16) were collected from the last compilation. It proved to be especially useful as it contains references to the joke sources, which are either earlier joke compilations (e.g., "Belaruskiya zharty", published in 1915) or data collected by ethnographers and folklorists in the 19th or early 20th century (e.g., folk texts collected in Western Belarus and published by Mikhail Fedarouski in the late 19th to early 20th century).

As for the Soviet jokes, in this paper I have used jokes from the above-mentioned joke compilations "Smejcesya na zdaroue!" and "Zharty, anekdoty, gumareski", which have separate sections on pre-Soviet and Soviet humorous folklore. I have also relied on the Soviet joke compilation "Belaruskiya narodnyja zharty" (1970), which, unlike other titles, only features jokes from the Soviet period. These joke books were compiled by folklorists and offer a great variety of joke texts on different subjects. The main limitation of these sources is that "Smejcesya na zdaroue!" and "Zharty, anekdoty, gumareski" were published in the Soviet times and, as explained above, do not include jokes that were unacceptable to the Soviet regime. Even "Zharty, anekdoty, gumareski", which was published 14 years after the demise of the USSR, still relies primarily on jokes published in the Soviet period. These sources thus do not reflect the actual humorous folklore of the time adequately. Yet they are among the few sources that provide us with at least some idea of the subject matter.

Most of the contemporary jokes used in my research were collected from two popular Belarusian Internet forums: http://forum.onliner.by/ and http://talks.by/. Each has special threads dedicated to jokes where all registered users can post jokes and comment on them. Although this type of communication is in a way similar to oral jokes transmission (Thielemann 2011: 151), it does not entirely mirror the processes of oral circulation. Indeed, Alan Dundes already noted in 1996 that "technology has helped spawn a new generation of folklore" (Dundes 1996: xiv)-however, in doing so the Internet has also displaced oral communication as the primary environment of joke circulation, making it impossible to ignore its influence when conducting a diachronic analysis.

A further methodological complexity arises from the fact that the primary informants of 19th century joke compilers were peasants, many of whom lacked even a primary education, while modern forum users are generally assumed to be educated urban dwellers. However, this class difference mirrors the overall change in the socioeconomic configuration of Belarusian society. Whereas in the 19th century ethnic Belarusians predominantly lived in rural areas and accounted for just 14\% of urban population (Kosareva 2010: 140), in the 21st century, following decades of industrialisation and urbanisation, rural dwellers make up only $26 \%$ of the entire population (Zinovskij 2010). Thus both the jokes told by 19th century peasants and the jokes shared online by 21 st century Internet users can be argued to be reasonably representative of Belarusians as an ethnicity relative to the time of the jokes' circulation.

In total I used 287 jokes for the analysis ${ }^{1}$. The chronological distribution is as follows: 
Table 1. Chronological distribution of jokes used for the present research

\begin{tabular}{|c|c|c|c|}
\hline $\begin{array}{c}\text { 19th and early 20th } \\
\text { century }\end{array}$ & Soviet & Modern & $\begin{array}{c}\text { 19th and early 20th } \\
\text { century }\end{array}$ \\
\hline 16 & 62 (59 unique plots) & $\begin{array}{c}209 \text { (203 unique } \\
\text { plots })\end{array}$ & 16 \\
\hline
\end{tabular}

It is evident from the table that the chronological distribution is very uneven in terms of the number of jokes due to both the limited availability of sources and the lesser relative importance of the subject of education in pre-Soviet folklore. Additionally, many of the jokes were published in the Soviet era, when the main intention behind their publication was to highlight the class struggle in the Russian Empire, rendering the subject education of little interest to the joke compiler. Thus not only do modern jokes clearly outnumber jokes from the previous periods, but they also display a greater variety of plots and topics. While using school as a setting and teachers or pupils as joke butts, modern jokes touch on various subjects which are often unrelated to education as such. The school becomes a setting for ethnic, religious, social, gender, sexual and other kinds of conflicts and stereotypes, as well as a metaphor for the state of society in general. Consider, for example, the following jokes:
A lesson in a primary school. The teacher asks:
"Tell me, children, how are you coping with the crisis, how do you save money?"
Olechka says:
"We haven't eaten meat for half a year already..."
Vasechka says:
"We only brush our teeth once a day."
Then Vovochka says:
"We've kicked mom out of the house..."
"What are you saying, Vovochka, how can that be?!"
"Well, dad and I had a word: I don't need to be breastfed anymore, dad can't get an erection... And to feed her for the neighbour-no, thanks..."
"Hello and welcome to the Smartest People Show. And tonight's first nomination is 'The smartest teacher of the week'. Dear nominees, please introduce yourselves."
"I am Andrej and I teach Physics."
"I am Anton and I teach Literature."
"I am Sergey, this week I quit my job as a teacher and now I work at a bank."
"And Sergey is this week's smartest teacher."

These and a great number of other jokes reflect certain aspects of school as a setting for jokes but do not primarily address education as a process of acquiring knowledge and skills as such, focusing on other societal issues instead. Other jokes, however, focus on learning at school to a greater extent. From a statistical perspective, jokes where either the pupil or the teacher explicitly demonstrates some kind of knowledge in an educational context constitute about $46.8 \%$ of the unique joke plots I identified (130 out of 278). However, this proportion differs across the three periods:

Table 2. The proportion of jokes where knowledge is demonstrated

\begin{tabular}{|c|c|c|c|c|c|}
\hline \multicolumn{2}{|c|}{ 19th and early 20th century } & \multicolumn{2}{|c|}{ Soviet } & \multicolumn{2}{c|}{ Modern } \\
\hline Children & Adults & Children & Adults & Children & Adults \\
\hline $81,3 \%$ & $0 \%$ & $59,3 \%$ & $11,9 \%$ & $31 \%$ & $5,9 \%$ \\
\hline
\end{tabular}


Such jokes usually describe an episode of teacher-pupil interaction, parent-pupil interaction or pupil-pupil interaction. In a typical joke the teacher asks a question, to which the pupil replies in an unexpected manner. These interactions may take place at school, at home or in an unspecified setting.

The table above shows that in the 19th and early 20th century the majority of jokes that concerned school were about the knowledge one gets (or is supposed to get) there. Moreover, the jokes at that time did not question directly the educational level of parents and teachers.

In Soviet and especially post-Soviet times, the range of topics associated with school increased significantly. This led to a decrease in the proportion of jokes that reflect the primary function of school: getting formal education. And unlike the preceding era, in Soviet and contemporary jokes it is not only the pupils but also their teachers as well as other school officials and parents who demonstrate their knowledge, or lack thereof.

In the present paper I will focus mostly on jokes that question children's or adults' knowledge because such jokes help to understand people's attitudes towards imparting knowledge as the primary function of school. Other jokes about school, teachers and pupils will also be taken into consideration in order to present a more complete account of jokes about education.

\section{General remarks on education in Belarus}

According to the Russian Imperial Census of 1897, the level of literacy in the European part of the Russian Empire, which encompassed the modern states of Russia, Ukraine and Belarus was relatively low. Only $22.9 \%$ of the population could read and write. Education was mostly a privilege of nobility, merchants, state officials and priests (Saprykin 2009: 19). Getting a secondary and a higher education was mainly necessary (and possible) for those who occupied important state positions. Others were expected to get at most a primary education. New schools were gradually opening, but even primary school was not always accessible to peasants and the urban poor. Those who did get a primary education were mainly taught reading and arithmetic, as the goal of their education was to provide rural communities with clerks (Konstantinov et al. 1982). Education was also gender specific: only $13.6 \%$ of women were literate, compared to $32.6 \%$ of men.

During the Soviet period Belarus, alongside the other Soviet republics, experienced a dramatic increase in educational level. The Soviet government initiated a massive "Down with illiteracy" campaign: all illiterate citizens between ages 8-50 had to learn to read and write in either Russian or their mother tongue. In 1930 compulsory primary education was introduced (Rakunov 2011). As a result, many new schools were built and all children had an opportunity - and an obligation - to go to school. School became one of the most important ideological tools of the Soviet state, promoting new communist values to the emancipated masses. This role made it crucial for the Soviet state to expand the reach of education as widely as possible. As time passed, the USSR became increasingly industrialised and needed more qualified workers. As a result, eight-year education became compulsory and a lot of efforts were put into the spread of higher education.

Prior to World War II, Western Belarus, which was part of Poland between 1921 and 1939, had a very different educational system. Belarusian schools were closing down and children were encouraged (although not forced) to attend Polish schools which promoted the ideology of the Polish state. After Western Belarus became a part of the Belorussian Soviet Socialist Republic in 1939, the authorities tried hard to integrate its educational system with the one already established in the USSR. Primary and secondary education became compulsory, as it was elsewhere in the USSR. Consequently, during the Soviet times getting a secondary 
education transformed from a privilege into a necessity and a university degree became more and more prestigious.

After the collapse of the USSR these tendencies have continued in independent Belarus. Almost $100 \%$ of children get a secondary education and a large number proceed to higher education. In 2013 Belarus ranked fourth in gross enrolment ratio in tertiary education according to the UNESCO Institute for Statistics.

Inevitably, such a shift in educational level was accompanied by changes in people's attitude towards education. In order to understand these changes it is vital to place them in a broader context of social life. In the 19th century the emergence of new schools and new opportunities for education since the 1830s (even though it was only primary education for most) in the European part of the Russian empire (see Konstantinov et al. 1982) was parallel to the traditional way of life of the majority of the population. There was no particular demand for educated people in rural and even in some urban areas.

By contrast, the changes in education in the Soviet period were accompanied by other significant changes in society: rapid development of heavy industry, creation of collective farms and urbanisation. All these policies were interconnected: collectivisation helped to collect money for industrialisation and the spread of education provided the industry with qualified workers. However, these connections were not always evident to the common people involved. They were forced to adjust their lives to the evolving environment but the changes in their views and attitudes were not as rapid as the changes in state policy.

The fall of the USSR challenged the established social order in Belarus. The sovereignty and independence placed new demands on the educational system. The language problem became acute with the introduction of compulsory Belarusian-language education (Leshchenko 2004: 335). However, contrary to the Soviet period, the government did not attempt to build an entirely new educational system, opting rather to adjust the system it inherited from the USSR to the new conditions.

In the following sections, I will trace the evolution of the educational system and the changing attitudes towards the education through the prism of folk jokes.

\section{19th and early 20th century jokes}

As education at the time was neither widely available nor particularly useful to the majority of the population, jokes about education seem to have occupied a peripheral position in pre-Soviet Belarusian humorous folklore. Out of more than 700 jokes found in the joke compilations that I used for my research, only 16 touch upon the issue of primary and secondary education. The few jokes that were collected and published at that time indicate that formal education was widely considered useless and was juxtaposed to the more practical skills that children acquired at home. Getting knowledge that could not be used in everyday chores was deemed a waste of time; moreover, for peasants' children it could even be harmful. Consider the following joke:

One inhabitant of Polesse (a region on the Belarusian-Ukrainian border populated mostly by peasants) sends his son to study "science". After studying away from home for some time, the son returns home and his father is very happy to see him.

"Oh, my son, tell me something in Latin."

"What do you want me to say?" the son replies.

"What do you call a student in Latin?" the father asks.

"Skubent ${ }^{4}$, " the son replies.

"And what do you call fire?" asks the father.

"Zhigato. In Latin it's all called differently!" replies the son.

"And tell me, what do you call a cat?" 


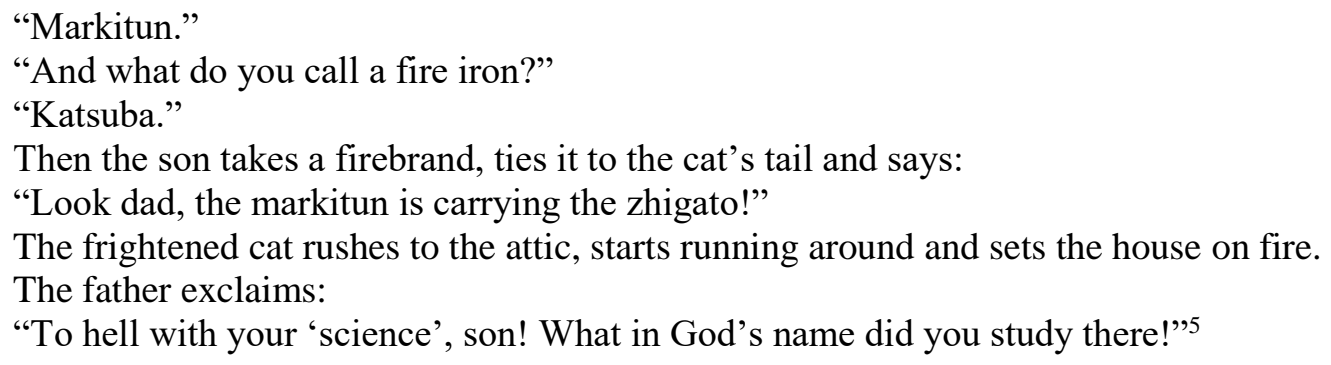

Curiously, in many folk jokes going to school was associated with studying Latin. Similar jokes can also be found in the Ukrainian folklore of that period (Nud'ga 1957: 186). This had little to do with the reality of school education in the 19th and early 20th century, however. In the 19th century peasants could typically only receive a primary education, whose curriculum did not include Latin. However, "studying science" in Belarusian folk jokes of the time was associated with Latin because this was the kind of knowledge Catholic priests and nobility possessed, or were deemed to possess. Latin, therefore, became the symbol of education: unattainable and impractical at the same time. Interestingly, some of the joke plots involving a son who studied Latin still remain popular (Astapova 2016: 333-334), which demonstrates the continuity of the humorous tradition.

In some cases formal education is explicitly contrasted with learning the necessary skills at home. Jokes indicate that passing knowledge and skills from father to son was considered more preferable to studying obscure and impractical "science" at school. Studying at school was only important if one wanted to get a job of a state official, a doctor, a teacher or a priest. However, in the peasant community of the time getting such jobs meant violating the traditional way of life that revolved around hard work in the fields. State officials, who did not produce any tangible product, were the typical joke butts. It is possible to see a parallel here with lawyer jokes in early modern England that were popular because "in a society where most of the inhabitants work in agriculture or in the production of basic material items... the lawyers' activities seem to produce nothing and to be based on nothing" (Davies 2011: 48). This is indicative of a tension between the mind (represented by lawyers or state officials and associated with education) and the body (represented by peasants' work and their way of life).

Other jokes touch upon the religious aspect of education. This is a more realistic theme since many primary schools at that time was operated by the Russian Orthodox church (Saprykin 2009: 53), which was the dominant religion in Belarus at the time, largely due to state support (Filatava 2006: 14, 29). The Catholic church also retained a strong position with the help of the Belarusian and Polish nobility (ibid.: 77-78) and had its own educational institutions (ibid.: 87). Most of the jokes in fact do not specify whether the setting of the joke is an Orthodox or a Catholic school. The typical plot of these jokes involves the priest (who is also a teacher) asking a question about some religious issue and a pupil giving an answer based on common knowledge and common sense:

The teacher asks a pupil: "Why did God banish Adam and Eve from paradise?"

"Because they ate a green apple, and one shouldn't eat green fruit because he will then have stomach ache."

The teacher asks: "Who was St. Paul?"

"I don't know," the pupil replies.

The teacher prompts: "Ap... ap..."

The pupil ventures: "Apothecary?"7

In Soviet-era joke books the consensus on jokes dating to this period and concerning religious education was that the jokes demonstrated the Belarusians' disdain towards religion (e.g., 
Fiadosik 1978: 58). This went in line with the Communist government's official atheist policy. However, the shift from a religious script to a secular one in the jokes cited above does not indicate a negative attitude towards religion as such. Rather, it demonstrates the ability of children to blend the "abstract" knowledge that they receive at school with the reality of their everyday lives. In contrast to the previous group of jokes that ridicule formal education, the jokes about religious education do not always stress the uselessness of learning. Their core theme is the children's ingenious ability to establish a common ground between the formal and often impractical knowledge they get at school and their day-to-day experiences and knowledge.

What both types of have in common is that they highlight the formal and impractical side of education. Belarusian rural society was still very rigid in the 19th and early 20th century. When something new-like education in this case - was introduced from the outside (by the government, church or private landowners), it was difficult to locate a place for it in the traditional way of life. This explains both the small number of jokes and the ideas behind them: formal education was not widespread because the majority of population regarded it as impractical and sometimes even harmful as it distracted children from their work in agriculture.

\section{Soviet jokes}

Jokes dating to the Soviet period express mixed feelings about education. These jokes can be separated into two groups. The first group portrays school as an institution where any kind of interaction may take place and where all the actors-pupils, teachers, school officials and parents - have well-defined roles which they sometimes continue to play even outside school. The second group of jokes is about education as an assortment of knowledge in different fields. As Table 2 shows, jokes about knowledge become somewhat less popular than in the previous epoch but still constitute the majority of jokes about education.

With the introduction of compulsory education attending school became a necessity. Some of the jokes suggest that it was normal for parents to support their children financially while they were getting an education, in contrast with the previous period when education was considered a waste of time and money. However, parents and other "grown-ups" did not always understand the true value of education. The reason it was important to attend school was that otherwise one would be punished by the Soviet state. But learning as such was not necessarily a big motivation. This was especially evident during the first decades of Soviet era when the majority of the Soviet population was still rural and formal education did not meet their needs (Kolyhalov 2010). Perhaps, it was this conflict between the "old" attitude of parents towards education as something impractical and useless and the "new" reality of compulsory education that resulted in the emergence of jokes where not only children but also adults demonstrate their knowledge — or, rather, ignorance. The following joke illustrates this:

Petya comes home from school crying because he has received a bad grade. His father asks him:

"What did you get this "two" for?"

"I couldn't find the greatest common divisor of two integers..."

The father scratches his head:

"Incredible, they still haven't found it. Twenty years ago they asked me the same thing at school.""

It is not only parents who demonstrate a lack of academic knowledge. Sometimes, teachers and other school officials were mocked too. This differs dramatically from the pre-Soviet jokes in my sample, where teachers represented an unquestionable authority in educational aspects:

During an exam a school inspector decides to test the pupils' knowledge himself: 
"Who broke the wall of Carthage?" he asks one of them. "Let's have Victor Lazuka answer that." "I didn't break it," the pupil replies defensively.

"He'd never do something like that!" the teacher supports the boy. ${ }^{10}$

It can be observed in these jokes that the figures of the parent and the teacher, which in earlier epochs commanded a high level of authority, were beginning to lose their status as unquestionable figures of power. The jokes also suggest that the parents' lack of appreciation for formal education stemmed not least from the fact their own education left much to be desired. Finally, acquiring some "abstract" and "theoretical" knowledge at school still lacked a link with children's future careers that were mostly in industry and agriculture. In fact, receiving formal education was sometimes considered a burden rather than an opportunity; in the Soviet era many people had to learn how to read and to write after their working day at socalled "night schools". Consider the following example:

"Can you read?"

"Yes, I can, but only at night."

"And during the day?"

"I can't. I studied at a night school."11

Skills and knowledge that children were supposed to get at school did not have much value of their own; they only mattered insofar as they were needed to fulfil the formal requirements imposed by the state. In contrast to the previous epoch, school education does not harm pupils; however, it does not bring them many benefits either, leading pupils to question the value of theoretical knowledge gained in the classroom:

During a history class a teacher addresses a student:

"Tell me about Alexander the Great."

"I don't know."

"And who is Augustus? And Julius Caesar?"

"I don't know."

"You get a 'two'."

"Wait", the pupil replies, "Do you know Misha Sidarau?"

"No."

"And Zhora Kaplyukhin? Neither? So, why do you give me a 'two'? You have your own circle, and I have mine." 12

Another important change is the shift towards secular education which resulted in a dramatic decrease and then a total abandonment of jokes about the religious aspects of education. In Soviet schools children were supposed to acquire a "scientific" perspective on reality. This went in line with the wider paradigm of (ideologically conditioned) "scientific rationalism"; consider, for example, how one of the most authoritative sources of the Soviet era, The Great Soviet Encyclopaedia, stressed that scientific and technological advancement progress called for a systematic increase of knowledge among the working class (Great Soviet Encyclopedia n.d.). Consequently, joke protagonists are usually questioned in chemistry, geography, history, and so on.

Also, as already mentioned, in the Soviet era the content of education was to a great extent determined by the ideological needs of the state. Unfortunately, the strict censorship of joke publications led to the almost total omission of jokes focusing on the ideological aspect of education. The jokes' comic effect could be derived from pupils' ignorance in the sciences but not their ignorance of the Communist party's policy. Only a few jokes address the issue of ideology and even those stay on its periphery. For example, one of the core aspects of the Soviet ideology was the notion of the "dictatorship of the proletariat" during the transitional phase 
between the abolition of capitalism and the establishment of communism (Britannica n.d.). Teaching this concept to school children meant nurturing a respect towards industrial workers and their jobs, as well studying various theoretical and practical aspects of these jobs at school. In some jokes, the students' response to this facet of education mirrors that to the more scientific knowledge described above:

After a lengthy explanation about weavers' work and what clothes are made of, a teacher asks one of the pupils:

"Tell me, Peragud, what are your trousers made of?"

"My Granny's skirt."13

The examples above demonstrate that in the Soviet period education became a secular institution which was a crucial part of social life. However, its nominal function, providing children with knowledge, was not always recognised by both children and adults. The remnants of the old attitude towards school learning as impractical and remote from real life were still present in many Soviet jokes. This was typical of the perception of the Soviet official sphere in general: people tended to comply with the regulations that were imposed on them, but at the same time they often perceived them as useless and unfair (Yurchak 1997).

\section{Modern jokes about education}

The jokes that emerged over the last 25 years or so still show an ambiguous attitude towards education. New topics emerge in the jokes about education. And, as I pointed out earlier, these topics have little to do with education as such.

The school as an institution still remains a butt of jokes and is portrayed as a place that children want to avoid. In one joke, for example, a schoolgirl wonders why they put up a street sign saying "Slow down, school ahead" if no one would want to rush to school anyway ${ }^{14}$. A similar joke also exists in contemporary Ukrainian folklore with Vovochka as a protagonist ${ }^{15}$.

Some modern jokes still feature characters who lack any appreciation of education and academic knowledge:

"Daddy, everyone makes fun of me at school. They say my parents are uneducated!"

"What's a school, son?"16

A distinctive feature of modern jokes is school children's awareness about sexuality and their willingness to demonstrate this awareness both in the classroom and outside of school. This feature is closely connected to the Vovochka joke cycle that emerged and became popular in late decades of the USSR and continues to be widespread not only in modern Belarus but also in Russia, Ukraine and other Russian-speaking countries. Vovochka often acts as the fool, transforming serious and formal rituals into vulgar, corporeal practises (Belousov 1996: 176178), including sexual activity which, if not explicitly referred to, is at least hinted at:

On the first of September the parents get Vovochka ready for school, see him off and wait impatiently for him to return. Finally, Vovochka is back. He kicks the door open and immediately confronts his parents: "You told me a stork had brought me! You told me you had found me in the cabbage patch! Now I know where children really come from!!!" Then he adds pensively: "And tomorrow I'm going to find out how they get there..."17

The teacher says: "And now I will tell you how the first person appeared in our world." Vovochka says from a desk in the back: "I'd much rather hear about how the third person appeared!"18 
A class in Arithmetic. The teacher asks Vovochka: "Imagine I give you 200 dollars. You give $\$ 50$ to Mashen'ka, \$50 to Lenochka and \$50 to Natashen'ka. What will you have?"

Vovochka replies: "An orgy..."19

Vovochka is the typical protagonist in the jokes about education that touch on the subject of sex. However, the jokes themselves may be appropriated from other joke cycles. For example, one of the jokes is based on a popular humorous anecdote about anthropology professor A.C. Haddon, which was often retold in American and British educational institutions in the 1940s and 1950s (Brunvand 1960) and has other variations that do not involve Vovochka (Ilchenko \& Panchenko 2012).

The Belarusian version goes as follows:

Girls from Vovochka's class decided that they would leave the classroom whenever Vovochka says something vulgar. One day, Vovochka enters the classroom and says:

"They started building a whorehouse near the school."

The girls rush towards the exit.

Vovochka says:

"Where are you going, whores? They have just laid the foundation." 20

Here is the earlier American version, published by Jan Brunvand, and much less sexual in nature:

He [Professor Haddon] was discussing Sociology and, as happened so often when he was talking about his Torres Straits Islanders, had exceeded his hour. He was describing how in some islands the women, not the men, made the proposals of marriage, when the women students from Girton College, knowing that their cab would be waiting impatiently outside, unostentatiously slipped out at the back. The temptation was too great. He called out, 'No hurry, there won't be a boat for some weeks. $^{21}$

Jokes about education that involve sexual behaviour are not limited to the Vovochka joke cycle. Some modern jokes have protagonists with different names or do not specify their names at all. The large number of such jokes reveals the opposition between formal, "academic" knowledge that children are deemed to get at school and "real-life" knowledge that they possess or are willing to obtain. This "real-life" knowledge may also concern other issues, for example, alcohol consumption, as in the joke below:

A class in Algebra:

$0.5+0.5=$ ?

An excited voice from the back: "A litre!"22

This example also clearly shows that children still tend to adapt the abstract knowledge that they get at school to their everyday lives. This feature has been present in jokes about education since the 19th century, but in modern jokes such "real-life" knowledge has transformed beyond recognition. Children tend to be interested in and are knowledgeable about sex, alcohol and drugs. These topics are also popular in the jokes that school children tell each other because they are rarely presented with an opportunity to discuss them with adults (Lur'e n.d.). Children express this knowledge and contrast it to the knowledge they get at school. Moreover, the jokes highlight the contrast between children and their parents or (more often) teachers in these matters. Children express their "streetwise" knowledge freely, even boastfully. Teachers, on the other hand, tend to know little about sex, alcohol and drugs - or try to conceal their knowledge. In this case we may suggest that children play the roles of mediators. They speak freely about matters that are omnipresent in contemporary society but that are considered 
"inappropriate" and are thus largely invisible. As one of the most conservative institutions, school (personified by teachers) tries to prevent children from discussing such "inappropriate" matters and make them focus on academic knowledge. But the teachers themselves sometimes accidentally reveal their concealed thoughts, thus proving that the issues articulated by children are part of our society:

During a lesson the teacher asks: "Masha, what would you like to become?"

"A ballet dancer!"

"And what would you like to become, Viten'ka?"

"An astronaut!"

"And what would you like to become, Vovochka?"

"A sex therapist!"

"Can you explain?"

"It's very simple. Look out of the window. There are two girls there. They are eating ice-cream. One of them is licking it and the other one is sucking it. What is your opinion, which one of them is married?"

"Maybe the one who is sucking," suggests the embarrassed teacher.

"No! The one that has a wedding ring on her finger! And when I become a sex therapist, I will treat people like you!"23

Contemporary jokes clearly show that the function of school has undergone a serious transformation. School is still a place where children get an education. However, this does not mean that children care deeply about academic knowledge. They still show more interest in the knowledge concerning the "taboo" but still omnipresent issues of sex, alcohol, etc.- - yet they are now trying to use school to obtain this knowledge.

School has also become a place where various aspects of contemporary life are revealed and discussed. As jokes are no longer censored as they were in the Soviet era, we can find in them reflections of many of these issues.

\section{Conclusion}

Jokes about education show that, while over the last two centuries the educational system in Belarus witnessed several dramatic changes, the change in the attitude towards school not been as abrupt. The value of getting an education has only been recognised recently, and the kind of education that is desirable often has little to do with the official educational system which is still regarded as something negative, or at least backward. The jokes of all the three periods celebrate the precedence of practical knowledge and skills over the largely theoretical concepts studied at school. The specific ways of celebrating it can be different: from showing the school as a harmful, or at least completely useless institution in pre-Soviet jokes to portraying an environment where abstract academic knowledge taught formally coexists and clashes with "streets smarts" shared by children, often in violation of implied societal taboos. Even in the latter case, however, the links between education and practise are only beginning to emerge and are typically established not by the educational system but by the pupils themselves.

Even more importantly, jokes about education are not only about education. This is similar to Oring's (2008: 70) observation that jokes about blondes are not really about blondes and even not about women - they are signs of our time and its changing values. In a similar vein, jokes about education, while not representing social reality in a direct way, point to the changing role of education in Belarusian society and the transformation of aspects that are touched upon in a school setting.

The educational system has a specific social institution in the Belarusian society. On the one hand, it was, and to a certain extent still is, monopolised by the state and therefore reflects 
the state's priorities and ideology. Consequently, jokes about education may reveal some of these principles and people's attitudes towards them. However, state ideology is not manifested directly in the jokes about education. School has been pervasive in Soviet and modern Belarus: with the introduction of compulsory secondary education it became a fact of life for every family. This resulted in the transformation of its functions. Rather than providing children with knowledge, school has become a space of social interaction that reflects various current aspects of the Belarusian society.

Another question, which warrants further investigation, is to what extent Belarusian jokes about education are different from those of neighbouring nations. In particular, it remains an open question whether Belarusian jokes are demonstrably different from Russian and Ukrainian counterparts, given the close cultural and historical proximity, the common use of the Russian language, and the relatively weak national identity of Belarusians (Eke \& Kuzio 2000: 527). Studying online jokes makes this question particularly challenging, as Internet folklore is not affected by the boundaries of nation states and is nearly impossible to localise in a particular nation. The present study, for the sake of clear focus, essentially eliminated the cross-cultural aspect from the discussion by focusing on two predominantly Belarusian web forums. Yet as a vector for future research, this question seems intriguing, if problematic in practical terms.

\section{Acknowledgements}

This study was supported by the Estonian Ministry of Education and Research (IUT 22-5), and by European Union through the European Regional Development Fund (Centre of Excellence in Estonian Studies).

\section{Notes}

${ }^{1}$ Some of the Soviet and modern joke plots were represented by several plot variations.

The total number of unique joke plots is 278 .

${ }^{2}$ Cited from:

http://forum.onliner.by/viewtopic.php?t=1020293\&p=13013010\#p13013010

${ }^{3}$ Cited from: $\mathrm{http}$ ///forum.onliner.by/viewtopic.php? $\mathrm{t}=14053 \&$ start $=540$

${ }^{4}$ Here and elsewhere in this joke the protagonist uses non-words that mimic Latin (or at least its perception by Belarusian peasants).

${ }^{5}$ Cited from: Fiadosik 2005: 129-130.

${ }^{6}$ Cited from: Suzin 1987: 15.

${ }^{7}$ Cited from: Fiadosik 2005: 116.

${ }^{8}$ This is the equivalent of an "F" grade in the Soviet and post-Soviet education systems.

${ }^{9}$ Cited from: Fiadosik 2005: 349-350.

${ }^{10}$ Cited from: Byaspaly 1970: 108

${ }^{11}$ Cited from: Fiadosik 2005: 278.

${ }^{12}$ Cited from: Fiadosik 2005: 340.

${ }^{13}$ Cited from: Byaspaly 1970: 109.

${ }^{14}$ Cited from: http://talks.by/showthread.php?t=14265317\&page $=48$

${ }^{15}$ Cited from: http://anekdotu.org.ua/tag/shkola/page/10

${ }^{16}$ Cited from: http://talks.by/showthread.php?t=14265317\&page $=48$

${ }^{17}$ Cited from: http://forum.onliner.by/viewtopic.php?p=11365287\#p11365287

${ }^{18}$ Cited from: http://talks.by/showthread.php?t=14265317\&page $=30$

${ }^{19}$ Cited from: http://talks.by/showthread.php?t=14265317\&page $=40$ 
${ }^{20}$ Cited from: https://talks.by/showthread.php?t=2532253\&page $=3$

${ }^{21}$ Cited from Brunvand, J.H. (1960). 'Sex in the Classroom'. Journal of American Folklore 73(289), p. 250.

${ }^{22}$ Cited from: http://talks.by/showthread.php?t=14265317\&page $=35$

${ }^{23}$ Cited from:

http://forum.onliner.by/viewtopic.php?t=1020293\&p=39808131\#p39808131

\section{References}

Abrahams, R. (1976). 'The complex relations of simple forms', in Ben-Amos, D. (ed.), Folklore Genres. Publications of the American Folklore Society. Bibliographical and special series 26. Austin: University of Texas Press.

Achrymienka, P. (1962). Belaruskaja Litaratura i Falklor [Belarusian literature and folklore]. Minsk: Vydavectva Ministerstva adukacyi BSSR.

Akhmetova, M. (2009). "Rasstaemsya s detstvom, v shkole vypusknoj" (vypusknye teksty v postsovetskoj shkole)" ["We are parting with childhood, having a graduation ceremony at school..." (texts of graduation ceremonies in the post-Soviet school]. Aktual'nye Problemy Sovremennoj Fol'klorisiki i Izucheniya Klassicheskogo Naslediya Russkoj Literatury. Saint Petersburg: SAGA, pp. 220-232.

Alekseevky, M. (2010). 'Anekdoty ot Ziuganova: Folklor v sovremennoj politicheskoj bor'be' [Jokes from Ziuganov: Folklore in modern political struggle]. Antropologicheskij Forum, 12, pp. 1-36. Available at: http://anthropologie.kunstkamera.ru/files/pdf/012online/12_online_alekseevsky.pdf.

Arkhipova, A. (2003). 'Anekdot i ego Prototip: Genesis teksta i formirovanie zhanra' [The joke and its prototype: the genesis of the text and the formation of the genre]. Moscow: Institute for Advanced Studies in the Humanities of the Russian State University for the Humanities. Extended synopsis of the $\mathrm{PhD}$ thesis.

Arkhipova, A. (2013). Stirlitz Shel po Koridiru: Kak My Pridumyvaem Anekdoty [Stirlitz walked along the hallway: How we come up with anecdotes]. Moscow: Izdatel'stvo RGGU.

Arkhipova, A. \& Melnichenko, M. (2011). Anekdoty o Staline: Teksty, Kommentarii, Issledovaniya [Jokes about Stalin: texts, comments, studies]. Moscow: OGI.

Astapova, A. (2012). 'Contemporary student jokes: The body of texts and their genetic relations.' Journal of Ethnology and Folkloristics 6 (2), 97-117.

Astapova, A. (2016). Sovremennyj Studencheskij Anekdot: Syuzhetnyj Sostav i Tematicheskie Osobennosti [Contemporary student jokes: the body of text and their genetic relations]. Saint Petersburg: Russian Academy of Science, Institute of Russian literature. $\mathrm{PhD}$ thesis.

Attardo, S. (2001) Humorous Texts: A Semantic and Pragmatic Analysis. Berlin, New York: Walter de Gruyter.

Belousov, A. (1996). 'Vovochka', in Antimir Russkoj Kul'tury. Yazyk, Fol'klor, Literatura. Moscow: Ladomir, pp. 165-186.

Belousov, A. [ed.] (1998). Russkij Shkol'nyj Fol'klor: ot "Vyzyvanij” Pikovoj Damy do Semejnykh Rasskazov [Russian school folklore: from "summoning" the Queen of Spades to family tales]. Moscow: Ladomir; Nazran': AST.

Bode, V. [interview] (2012). 'Politicheskie anekdoty kak proyavlenie obshchestvennogo mneniya' [Political jokes as an indicator of public opinion]. Radio Svoboda. Available at: http://www.svoboda.org/a/24541763.html.

Bronner, S. (2012). 'The Jewish joke online: Framing and symbolizing humor in analog and digital culture', in Blank, T.J. (ed.), Folk Culture in the Digital Age: The Emergent Dynamics of Human Interaction. Utah: Utah State University Press, pp. 119-149. 
Brunvand, J.H. (1960). 'Sex in the classroom'. Journal of American Folklore 73 (289), pp. 250251.

Byaspaly, Z. [ed.] (1970). Belaruskiya Narodnyja Zharty [Belarusian folk jokes]. Minsk: Belarus.

Davies, C. (2011). Jokes and Targets. Bloomington: Indiana University Press.

Dundes, A. (1996). Sometimes The Dragon Wins: Yet More Urban Folklore From The Paperwork Empire. New York: Syracuse Univ. Press.

Education: Gross enrolment ratio by level of education. UNESCO Institute for Statistics. Online: http://data.uis.unesco.org/?queryid=142

Eke, S., Kuzio, T. (2000). 'Sultanism in Eastern Europe: The socio-political roots of authoritarian populism in Belarus.' Europe-Asia Studies 52 (3), pp. 523-547.

Encyclopædia Britannica. 'Dictatorship of the proletariat'. Available at: https://www.britannica.com/topic/dictatorship-of-the-proletariat.

Fiadosik, A. (1971). Trapnym Narodnym Slovam [With a witty folk word]. Minsk: Navuka i tekhnika.

Fiadosik, A. (1978). Prablemy Belaruskaj Narodnaj Satyry [Issues in Belarusian folk satire]. Minsk: Navuka i tekhnika.

Fiadosik, A. [ed.] (2005). Zharty, Anekdoty, Gumareski. [Jokes, anecdotes, witticisms]. Minsk: Belaruskaya Navuka.

Filatava, E. (2006). Konfessional'naya Politika Carskogo Pravitel'stva v Belarusi 1772-1860 gg. [Religious policy of the Tsarist administration in Belarus in 1772-1860]. Minsk: Belaruskaya navuka.

Frio, D. (2012). Classroom Voices on Education and Race: Students Speak from Inside the Belly of the Beast. Lanham, Md: Rowman \& Littlefield.

Frolova, O. (2010). 'Fol'klornye zhanry: vnetekstovoe prostranstvo i kontekst' [Folklore genres: extratextual reality and context], in Fol'klor: Tekst i Kontekst, Moscow: State Republican Centre for Russian Folklore, pp. 30-49.

Gilevich, N. (1970). 'Sila narodnaga smekhu' [The power of folk laughter], in Byaspaly, Z. (ed.), Belaruskiya Narodnyja Zharty [Belarusian folk jokes]. Minsk: Belarus, pp. 4-5.

Ilchenko, A. \& Panchenko, A. (2012) "Kuda vy, shlyukhi?": geroi sovremennykh anekdotov i migraciya fol'klornykh syuzhetov' ["Where are you going, sluts?": the protagonists of contemporary jokes and the migration of folk plots]. Antropologicheskij Forum 12, pp. 333-348.

Available

at: http://anthropologie.kunstkamera.ru/files/pdf/016/16_ilchenko_panchenko.pdf.

'Joke'. Merriam-Webster.com. Available at: http://www.merriam-webster.com/dictionary/joke.

Kabashnikau, K. (1969). Ad Tradycyjnaga Falkloru da Revaliucyjnaj Paezii [From traditional folklore to revolutionary poetry]. Minsk: Navuka i technika,

Kahanouski, G. (1989). Gei, Smali, Stralyaj, Malanka! [Hey, lightning, strike and shoot!], Minsk: Izdatel'stvo CK KPB..

Ken'ka, M. (2009). 'Da gistoryi belaruskaga anekdota' [On the history of the Belarusian joke]. Fal'klarystychnyja Dasledavanni 6, pp. 112-120.

Kolyhalov, D. (2010). Vvedenie Vseobshchego Obyazatel'nogo Nachal'nogo Obucheniya v Sovetskoj Rossii v 1923-1941 gg. [The introduction of universal compulsory primary education in the Soviet Russia in 1923-1941]. Available at: http://pspa.ucoz.ru/load/0-0-0$\underline{10-20 .}$.

Konstantinov, N., Medynsky, E. \& Shabaeva, M. (1982). Istoriya Pedagogiki [The history of pedagogy]. Moscow: Prosveshchenie. Available at: http://www.detskiysad.ru/ped/ped121.html.

Kosareva, S. (2010). 'Osobennosti stanovleniya natsional'nogo samosoznaniya Belorusov vo vtoroy polovine XIX - nachale XX vekov: Sotsial'no-etnicheskiy i obrazovatel'nyj aspekty' 
[The peculiarities of Belarusian's national self-consciousness formation in the second half of the 19th - beginning of the 20th c.: Social-ethnic and educational aspects]. Materialy IV Mezhdunarodnoj molodezhnoj nauchno-prakticheskoy konferentsii, Vol. 3. Pinsk: PolesGU, pp. 139-141.

Laineste, L. (2013) 'Can the "stripping of the boss" be more than a joke?' Integrative Psychological and Behavioral Science 47 (4), pp. 482-491.

Leshchenko, N. (2004). 'A fine instrument: two nation-building strategies in post-Soviet Belarus.' Nations and Nationalism 10 (3), 333-352.

Lobach, U. (2006). Etnagrafiya Belarusi (lekcyjny kurs) [The ethnography of Belarus (lectures)]. Novopolotsk: PSU. Available at: http://www.psu.by/images/stories/iff/personal/lobach/lobach_etnagrafia.pdf.

Lur'e, V. Detskij anekdot [Children's jokes]. Available at: http://www.ruthenia.ru/folklore/luriev4.htm.

'Lyubimye anekdoty!!!' [Favourite jokes!!!] Available at: http://forum.onliner.by/viewtopic.php?t=1020293.

Markie, P. J. (1994). A Professor's Duties: Ethical Issues in College Teaching. Lanham, Md: Rowman \& Littlefield.

Maslinsky, K. (2013) 'Shkol'naya disciplina skvoz' prizmu fol'klora' [School discipline through the lens of folklore]. Antropologicheskij Forum 19, pp. 176-194. Available at: http://anthropologie.kunstkamera.ru/files/pdf/019online/maslinsky.pdf.

Mel'nichenko, M. (2014). Sovetskij Anekdot (Ukazatel'Syuzhetov) [The Soviet joke: plots classification]. Moscow: Novoe literaturnoe obozrenie.

'Narodnaja Adukacyja' [Folk education]. The Great Soviet Encyclopedia. Online: http://bse.scilib.com/article080147.html.

Nud'ga. G. [ed.] (1957). Ukrains'ka Narodna Satyra i Gumor [Ukrainian folk satire and humour]. Lviv: Knyzhkovo-zhurnal'ne vydavnictvo.

Oring, E. (2008). Engaging Humor. Champaign: University of Illinois Press.

Oring, E. (2012). 'Jokes on the Internet. Listing towards lists', in Blank, T.J. (ed.), Folk Culture in the Digital Age: The Emergent Dynamics of Human Interaction. Utah: Utah State University Press, pp. 98-118.

Ozhegov, S. \& Shvedova, N. (1998). Tolkovyj slovar' russkogo yazyka [Russian language dictionary]. Moscow, Azbukovnik.

Perenis' Naseleniya Respubliki Belarus' 2009 Goda [2009 population census in Belarus]. National Statistical Committee of the Republic of Belarus. Available at: http://census.belstat.gov.by/pdf/BOOK-ru-RU.pdf.

Pervaya Vseobshchaya Perepis' Naseleniya Rossijskoj Imperii 1897 g. [First general census of the Russian empire 1897]. Available at: http://demoscope.ru/weekly/ssp/rus_age_97.php?reg=1.

Petrovsky, M. (1925). 'Anekdot' [Anecdote], in Literaturnaya Enciclopediya: Slovar' Literaturnykh terminov: v 2 t. Moscow: Leningrad: Izdatel'stvo L. D. Frenkel. Available at: http://www.endic.ru/lit/Anekdot-218.html.

Rakunov, V. (2011). 'Gosudarstvennaya politika v sfere shkol'nogo obrazovaniya v 1920-30kh godakh' [State policy in the education sphere in the 1920-1930s], in Informacionnyj Gumanitarnyj portal "Znanie. Ponimanie. Umenie". 1. Available at: http://www.zpujournal.ru/e-zpu/2011/1/Rakunov_Formal_Education/.

Saprykin, D. (2009) Obrazovatel'nyj Potencial Rossijskoj Imperii [The educational potential of the Russian Empire]. Moscow:: IIET RAN. Available at: http://www.ihst.ru/files/saprykin/book-education-pote.pdf. 
Severgin, V. (1804). Prodolzhenie Zapisok Puteshestviya po Zapadnym Provinciyam Rossijskogo Gosudarstva [Further notes on the trip around the Western provinces of the Russian state]. Saint Petersburg: the Imperial Academy of Science.

Shmeleva, E. \& Shmelev, A. (2005). 'Russkij anekdot v dvadcat' pervom veke (transformaciya rechevogo zhanra)' [Russian jokes in the twenty first century (the transformation of the genre of speech)]. Zhanry Rechi 4, pp. 292-298. Available at: http://www.dialog21.ru/media/2425/shmelevy.pdf.

Simons, R. D. (1986). 'The NASA joke cycle: The astronauts and the teacher.' Western Folklore 45 (3), pp. 261-277.

Suzin, L. [ed.] (1987). Smejcesya Na Zdaroue!: Belaruskiya Narodnyja Zharty, Anekdoty, Gumareski, Smyashinki. [Laugh for good health!: Belarussian folk jokes, anecdotes, witticisms, puns]. Minsk: Izdatel'stvo CK KPB.

'Svezhij anekdot' [Fresh joke]. Available at: http://talks.by/showthread.php?t=2532253.

Walker, S. \& Barton, L. (2013). Gender, Class and Education. London: Routledge.

Yankouski, M. (1983a). Niekatoryja Asablivasci Paetyki Satyrychna-Gumarystychnych Zhanrau Belaruskaga Falkloru [Some peculiarities in poetics of Belarusian folk humour and satire]. Viesci AN BSSR. Sieryja Gramadskih Navuk 5, pp. 84-89.

Yankouski, M. (1983b). Paetyka Belaruskaj Narodnaj Prozy [The poetics of Belarusian folk prose]. Minsk: Vyshejshaja shkola.

Yarnevsky, I. (1969). Ustnyj Rasskaz kak Zhanr Fol'klora [The oral tale as a folklore genre]. Ulan-Ude: Buryatskoe knizhnoe izdatel'stvo.

Yurchak, A. (1997). 'The cynical reason of late socialism: Power, pretense, and the anekdot.' Public Culture 9, pp. 161-188.

Zinovskij, V. (2010). 'Razmeshcheniye i Sostav Naseleniya Respubliki Belarus' po Dannym Perepisi 2009 g.' [The localization and structure of the population of the republic of Belarus by the 2009 census data]. Sociologija 3, pp. 111-116. 